\title{
Carbon dioxide degassing flux from two geothermal fields in Tibet, China
}

\author{
SHEN LiCheng ${ }^{1 *}$, WU KunYu ${ }^{1}$, XIAO Qiong $^{1} \&$ YUAN DaoXian $^{1,2}$ \\ ${ }^{1}$ Key Laboratory of Eco-environments in Three Gorges Reservoir Region, Ministry of Education; School of Geographical Science; Institute of \\ Karst Environment and Rock Desertification Control; Southwest University, Chongqing 400715, China; \\ ${ }^{2}$ Karst Dynamics Laboratory, Ministry of Land and Resources, Guilin 541004, China
}

Received October 9, 2010; accepted December 10, 2010; published online April 13, 2011

\begin{abstract}
Over geological time scales, Earth degassing has a significant impact on atmospheric carbon dioxide $\left(\mathrm{CO}_{2}\right)$ concentrations, which are an important component of global carbon cycle models. In Tibet, structural conditions and associated widespread geothermal systems lead to carbon dioxide degassing during geothermal water migration. We characterized the hydrochemical conditions of two geothermal fields on the Tibetan Plateau. The chemical composition of geothermal waters was controlled by K-feldspar and albite. Geothermal waters in the Langjiu geothermal field were sodium chloride type and those of the Dagejia geothermal field were sodium bicarbonate type. Simulations of $\mathrm{CO}_{2}$ partial pressure within the two hydrogeothermal systems showed that $\mathrm{CO}_{2}$ degassing occurs during hot water migration from the aquifer to the surface. Carbon dioxide degassing flux from the Langjiu geothermal field was estimated to be $\sim 3.6 \times 10^{6} \mathrm{~kg} \mathrm{~km}^{-2} \mathrm{a}^{-1}$, and that from Dagejia was $\sim 3.3 \times 10^{6} \mathrm{~kg} \mathrm{~km}^{-2} \mathrm{a}^{-1}$.
\end{abstract}

carbon dioxide degassing, geothermal, Langjiu, Dagejia, Tibetan Plateau

Citation: Shen L C, Wu K Y, Xiao Q, et al. Carbon dioxide degassing flux from two geothermal fields in Tibet, China. Chinese Sci Bull, 2011, 56: 3783-3793, doi: 10.1007/s11434-011-4352-Z

The natural carbon cycle includes the conversion and migration of lithospheric, atmospheric, hydrospheric and biospheric carbon, primarily in the forms of carbon dioxide $\left(\mathrm{CO}_{2}\right)$, carbonate $\left(\mathrm{CO}_{3}^{2-}\right)$, bicarbonate $\left(\mathrm{HCO}_{3}^{-}\right)$, methane $\left(\mathrm{CH}_{4}\right)$, and formaldehyde $\left(\mathrm{CH}_{2} \mathrm{O}\right)$ [1]. $\mathrm{CO}_{2}$ is the most abundant atmospheric greenhouse trace gas, and in recent years research has shown that the deep crust is a large $\mathrm{CO}_{2}$ source [2-4]. Hydrogeothermal systems play a key role in mediating crustal $\mathrm{CO}_{2}$ outgassing to the atmosphere [4,5].

American geologist T. C. Chamberlin [6] (1843-1928) hypothesized the regulation of atmospheric $\mathrm{CO}_{2}$ concentrations through dynamic lithospheric interaction with the hydrosphere and atmosphere, which lead to alternating cold and warm periods typified by the Permian and Quaternary glacial-interglacial oscillations. Modern research is increasingly focusing on regional- and global-scale $\mathrm{CO}_{2}$ degassing

*Corresponding author (xqimei@swu.edu.cn; xqimei@126.com) from the deep crust [2-16], and over the past decade a large number of studies have shown that $\mathrm{CO}_{2}$ release from both volcanic eruptions and non-eruptive systems affects global atmospheric composition. These non-eruptive systems include geomagnetic anomaly zones, shallow earthquake zones, gravity anomalies and high heat flow zones [17-27]. Processes assumed to be common among these settings are the migration of magmatic fluids from the deep to the upper crust and then the surface, which results in both significant $\mathrm{CO}_{2}$ outgassing and associated changes in the chemical composition of shallow groundwater.

Researchers have applied $\delta \mathrm{D}, \delta^{13} \mathrm{C},{ }^{3} \mathrm{He} /{ }^{4} \mathrm{He}$ and other isotopic tracers to study crustal $\mathrm{CO}_{2}$ outgassing in the western Cordillera region of USA [28,29], the Himalayas [3,4,30], Italy [17-20,22-27,31], southeastern France [32], eastern China [33,34] and southwest China [16,35-40]. However, there are few studies of the processes and magnitude of non-volcanic $\mathrm{CO}_{2}$ degassing, especially fault deep 
fault zones and geothermal anomalies. Currently, there are three main approaches to assessing $\mathrm{CO}_{2}$ degassing flux: (1) through changes in $\mathrm{CO}_{2}$ molar concentrations or enthalpy that occur during the migration of geothermal fluid between deep aquifers and the surface [25]; (2) measuring $\mathrm{CO}_{2}$ concentrations directly at particular grid sampling densities to calculate $\mathrm{CO}_{2}$ flux [26]; and (3) applying infrared remote sensing techniques to measure and calculate $\mathrm{CO}_{2}$ flux at regional scales [41].

Tibet Autonomous Region (Tibet for short) is one of the most tectonically active regions in the world, and its structural conditions and associated widespread geothermal systems lead to $\mathrm{CO}_{2}$ degassing during geothermal water migration. In this study we characterized the hydrochemical features of geothermal waters in the Langjiu geothermal field, Gar County, and the Dagejia geothermal field in Ngamring County, western Tibet, China, and calculated $\mathrm{CO}_{2}$ degassing flux in these two areas.

\section{Regional geological setting}

On the Tibetan Plateau there are two large-scale EW trending suture zones (Indian River-Yarlung-Zanbo suture (IYS) and Bangong Lake-Nujiang suture (BNS)), which are important geological and geomorphological boundaries divide the plateau into three tectonic blocks: north, central and south (Figure 1(a)). Large-scale uplift of the Tibetan Plateau has been occurring since the Miocene, and east-west extension occurred subsequently, the age range from $18.3 \pm 2.7$ to $13.3 \pm 0.8$ Ma B P [42], which formed a series of normal fault systems that bisect the IYS and BNS, some of which have developed into rift and grabens [43-46]. The grabens are well-known locations of Himalayan geothermal zones [47].

Geothermal waters on the Tibetan Plateau contain characteristic signatures, in particular dissolved gasses, reflecting the regional processes of collision and uplift, and the nature and spatial distribution of source rocks and in both the upper crust and the mantle. The geothermal gases in Tibet are subdivided into a dominant $\mathrm{CO}_{2}$-type and less common $\mathrm{N}_{2}$-type [39].

Here, we assigned geothermal anomaly districts on the Tibetan Plateau into one of the two types based on according to the occurrence of the geothermal deposits sediments travertine and silica sinter. The Langjiu geothermal field is typical travertine type and the Dagejia geothermal field is silica sinter type.

\subsection{Langjiu geothermal field}

The Langjiu geothermal field is located in Gar County $\left(80^{\circ} 21^{\prime} 40^{\prime \prime} \mathrm{E}, 32^{\circ} 21^{\prime} 48^{\prime \prime} \mathrm{N}\right)$ at $4500 \mathrm{~m}$ above sea level (a.s.l.) on the northwest margin of the Gangdisê-Nyainqêntanglha microplate, which is bounded by the Shiquanhe-Namco fault to the north and the Yarlung-Zanbo suture in the south (Figure 1(a)). The local geology is dominantly travertine. In the 1970s, a geothermal survey was conducted at the site by the Tibetan Plateau Comprehensive Scientific Expedition Team [48]. In the 1980s the local government built a geothermal power plant at the site, but it was abandoned soon after completion due to it not meeting local energy needs [49]. In 1987, a team from the Chengdu Institute of Geology completed a detailed geological map $(1: 5000)$ of the region $^{1,2)}$. Subsequently, detailed studies of the geothermal areas were conducted by Tong et al. [49] and Liao et al. [50].

The main stratigraphic units exposed in the region ${ }^{1,2,3)}$ [51] are: the Oligocene-Miocene Rigongla group $\left(\mathrm{E}_{3} \mathrm{~N}_{1} r\right)$ comprising purple-brown-red sandstones and conglomerates and calcareous mudstones; the Early Cretaceous Langjiu group $\left(\mathrm{K}_{1} l\right)$ comprising trachytes, basalts, rhyolites and bioclastic limestones; the Early Cretaceous Duoai group $\left(\mathrm{K}_{1} d\right)$ comprising basalts, tuffs, dacites, andesites and bioclastic limestones; the Early Cretaceous Tuocheng group $\left(\mathrm{K}_{1} t\right)$ comprising biotite dacites, rhyolites and tuffs; the Triassic Tongtangna group $\left(\mathrm{T}_{1-2} t\right)$ comprising dark gray-yellow dolomites and $\sim 2 \mathrm{~m}$ thick silicified limestone breccias at the base; and the Late Permian Xiala group $\left(\mathrm{P}_{3} x\right)$ comprising limestones and purple-red cherts.

The geothermal reservoirs in the Langjiu field are fractured granites, the roof rocks of which are not developed fully $[48,49]$. This enables the geothermal waters to mix with cold waters, which promotes the formation of a geochemical barrier. At present geothermal issues from a waste pipe at the former power plant (Figure 2(a)) enabling its geochemical analysis, with only changes in temperature and pressure.

\subsection{Dagejia geothermal field}

The Dagejia geothermal field is located in Ngamring County, Xigazê Region, Tibet $\left(85^{\circ} 44^{\prime} 45^{\prime \prime} \mathrm{E}, 2^{\circ} 36^{\prime} 00^{\prime \prime}-29^{\circ} 36^{\prime} 20^{\prime \prime}\right)$, at $5100 \mathrm{~m}$ a.s.l. It is situated in the middle of the Indian River-Yarlung-Zanbo suture and the southern margin of the Gangdise continental margin magmatic arc [54] (Figure 1(a)). The main kind of thermal spring in this region is geysers, and the hydrogeothermal height reaches $\sim 2 \mathrm{~m}$. There are also several smaller intermittent geysers and tens of thermal

1) Chengdu Institute of Geology Scientific Expedition Team to Ali. Scientific Investigation Report of Langjiu Geothermal Fields in Ali, Tibet, 1988, Internal data.

2) Chengdu Institute of Geology Scientific Expedition Team to Langjiu. Reconsideration of development prospects of Langjiu geothermal field, 1989, Internal data.

3) 1:250000 Geological Map for Shiquanhe. 


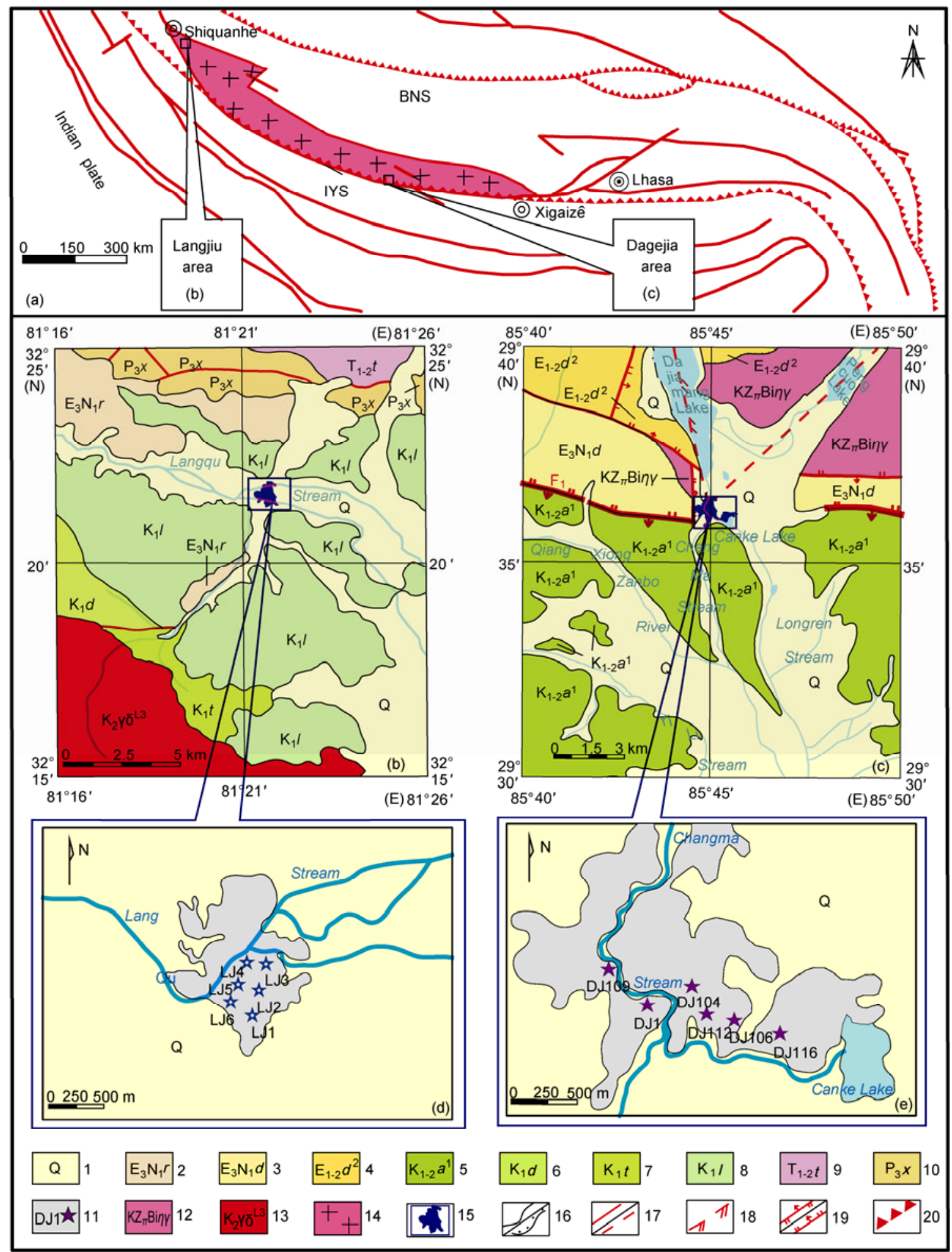

Figure 1 Structural units of the Tibetan Plateau [52,53] and geology of the Langjiu and Dagejia geothermal fields ${ }^{4,5}$. 1, Quaternary sediments; 2, Oligoceneearly Miocene Rgongla group; 3, Paleogene Dazhuka group; 4, Paleogene Dianzhong Group sec; 5, Cretaceous Angren Group; 6, Early Cretaceous Duoai Group; 7, Early Cretaceous Tuocheng Group; 8, Early Cretaceous Langjiu Group; 9, Triassic Tongtangna Group; 10, Late Permian Xiala Group; 11, sampling locations; 12, monzogranites; 13, granodiorites; 14, gangdise magmatic arc; 15, geothermal field; 16, stratigraphic boundary; 17, observed/inferred faults; 18, inferred transtensional faults; 19, observed reverse faults/normal faults; 20, sutures: IYS, Indian River-Yarlung-Zanbo Suture; BNS, Bangong Lake-Nujiang River Suture.

4) See footnote 3) on Page 3784.

5) 1:250000 Geological Map for Sangsang. 

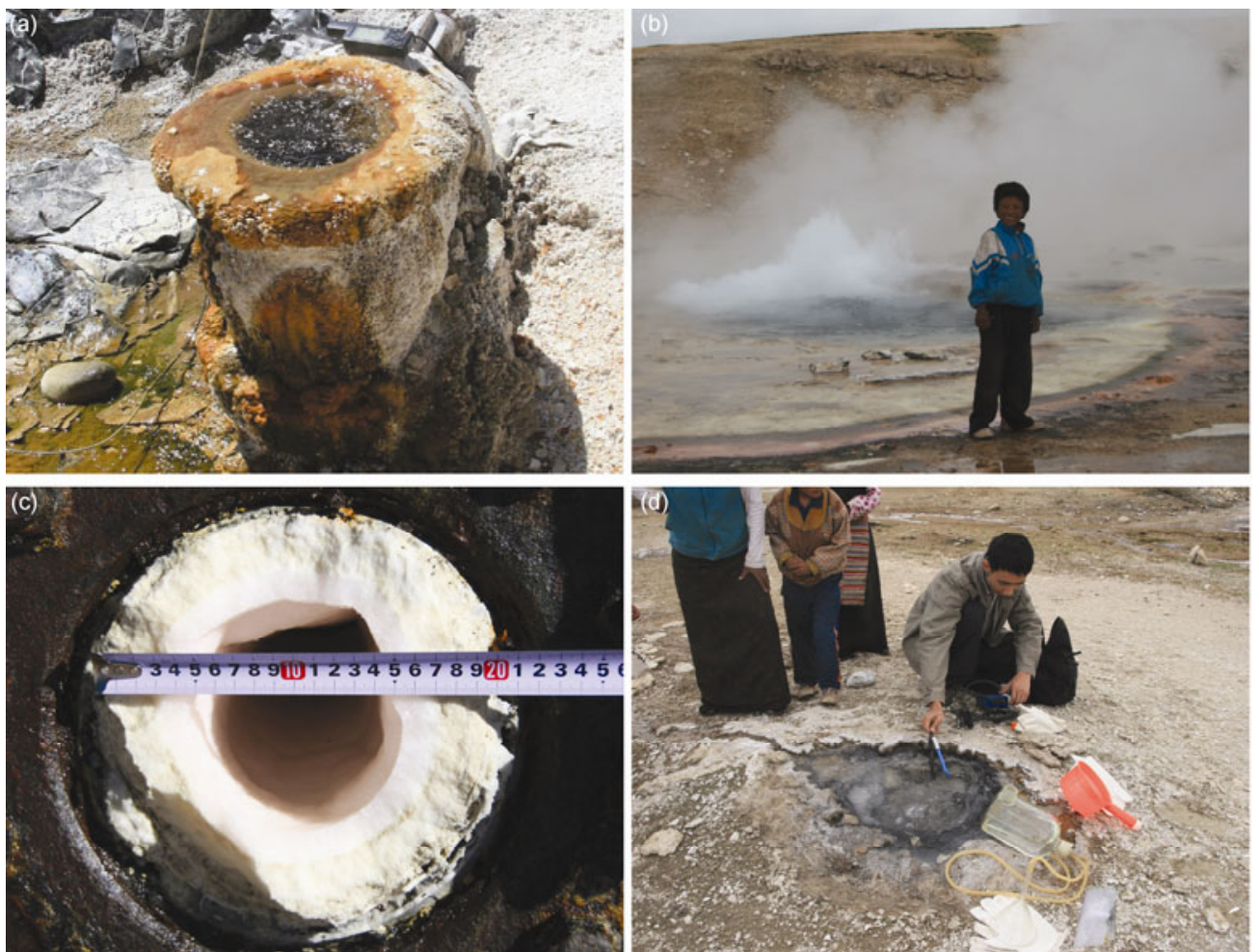

Figure 2 The photos of the geothermal field. (a) Thermal spring in the Langjiu geothermal field; (b) main fountain in the Dagejia geothermal field; (c) travertine in the Langjiu field; (d) in situ water quality monitoring and gas collection devices.

springs and hot water ponds (Figure 2(b)). All the thermal springs and other geothermal features are distributed along the Changma stream, which runs from Dajiamang Lake to Canke Lake (Figure 1(c), (e)).

This geothermal field has been much studied since the 1970s. The Tibetan Plateau Comprehensive Scientific Expedition Team conducted geothermal surveys and evaluations [48], and detailed investigations were conducted by Tong et al. [49] and Zhao et al. [39]. From the late 1980s to the 1990s detailed studies of the high-cesium deposits in the areas were conducted [54-58].

Most of the Dagejia geothermal field is composed of Quaternary sediments. Underlying exposed stratigraphic units are: Paleogene Dazhuka Group $\left(\mathrm{E}_{3} \mathrm{~N}_{1} d\right)$ sandstones and mudstones; Paleogene Dianzhong Group $\left(\mathrm{E}_{1-2} d^{2}\right)$ rhyolitic lavas, tuffaceous sandstones and rhyolites; and Cretaceous Angren Group $\left(\mathrm{K}_{1-2} a^{1}\right)$ dark gray and gray-black sandstones and fine sandstone-shales laminated sediments ${ }^{6)}$ [51].

Magmatic rocks exposed in study area are mediumgrained porphyritic hornblende monzogranites and mediumgrained porphyritic biotite monzogranites $(\mathrm{KZ} \pi \mathrm{Hb} \eta \gamma)$ which intruded in clastic stone during the Cretaceous ${ }^{6}$ [51]. The granite intrusions are the most likely heat source for the hot springs, and their granite micas and feldspars are likely the main sources of major hydrochemical elements $\mathrm{K}, \mathrm{Na}, \mathrm{Ca}$, $\mathrm{Mg}$.

The entire region has experienced strong tectonic activity, with well-developed east-west and northwest-southeast (Figure 1(c)). The Dagejia geothermal field lies within a small north-south oriented graben [47,59], the tensional nature of which presenting good conditions for extensive surface manifestation of geothermal waters.

\section{Sample collection and analysis}

\subsection{Field testing}

We field tested six hot springs in the Langjiu geothermal field (LJ1-LJ6) (Figure 1(d); Figure 2(a),(c)), and six geysers in the Dagejia geothermal field (DJ1: major geyser; DJ114, DJ106, DJ109, DJ112, DJ116: normal geysers) (Figure 1(e); Figure 2(b),(d)) and melt water, river water and lake water samples. We measured temperature $\left({ }^{\circ} \mathrm{C}\right.$, accuracy $\pm 0.1^{\circ} \mathrm{C}$ ), $\mathrm{pH}$, electrical conductivity (EC; accuracy $\pm 1 \mu \mathrm{S} \mathrm{cm}^{-1}$ ) in the field using a portable instrument (Hach, USA), and measured bicarbonate $\left(\mathrm{HCO}_{3}^{-}\right.$, accuracy \pm 0.1 $\left.\mathrm{mmol} \mathrm{L}{ }^{-1}\right)$ and calcium ions $\left(\mathrm{Ca}^{2+}, \pm 0.2 \mathrm{mmol} \mathrm{L}^{-1}\right)$ with a portable kit (Merck, Germany).

6) See footnote 5) on Page 3785. 


\subsection{Samples collecting and laboratory analysis}

We collected samples from each field testing site in clean polyvinyl fluoride bottles that were then sealed with wax. We analyzed for chlorine ion $\left(\mathrm{Cl}^{-}\right)$by aquametry (accuracy $\left.\pm 0.1 \mathrm{mg} \mathrm{L}^{-1}\right)$, sulfate ion $\left(\mathrm{SO}_{4}{ }^{2-}\right)$ by UV-spectrophotometry (accuracy $\pm 0.01 \mathrm{mg} \mathrm{L}^{-1}$ ), and fluorine ion $\left(\mathrm{F}^{-}\right)$by Metrohm 761 ion chromatography (accuracy $\pm 0.001 \mathrm{mg} \mathrm{L}^{-1}$ ). Cation samples were was acidified with $1: 1$ nitric acid $\left(\mathrm{HNO}_{3}\right)$ to avoid adsorption, and then tested with ICP-OES Optima 2100 DV spectrometer (accuracy $\pm 0.001 \mathrm{mg} \mathrm{L}^{-1}$ ). We collected gas samples in a Tedlar gas sampling device using the air displacement method [60], and tested them by gas chromatography mass spectrometry. All the testing was conducted in the Hydrochemical Analysis and Isotope Laboratories in the School of Geographical Science in Southwest University, Chongqing, China.

\section{Results and discussion}

\subsection{Hydrochemical characteristics}

Water temperature in both geothermal fields ranged from $80^{\circ} \mathrm{C}$ to $105^{\circ} \mathrm{C}$, and $\mathrm{pH}$ values were in the range 7.4-9.15, which means they were neutral to weakly alkaline (Table 1). Electric conductivity in these springs was high (1582-1848 $\mu \mathrm{S} \mathrm{cm}{ }^{-1}$ at Dagejia, and $2610 \mu \mathrm{S} \mathrm{cm}^{-1}$ at Langjiu), as was their degree of mineralization. The Dagejia and Langjiu fields had similar ranges of $\mathrm{K}^{+}, \mathrm{HCO}_{3}^{-}$and $\mathrm{F}^{-}$values. In general in Dagejia there were higher value ranges for $\mathrm{CO}_{3}{ }^{2-}$ and $\mathrm{SiO}_{2}$ than in Langjiu, and in Langjiu there were higher value ranges for $\mathrm{Na}^{+}, \mathrm{Ca}^{2+}, \mathrm{SO}_{4}{ }^{2-}$ and $\mathrm{Cl}^{-}$than in Dagejia.

The hydrochemistry of geothermal waters can be presented graphically in a classification diagram [61], and we present the cation and anion data in Table 1 thus in Figure 3. The Dagejia hot springs are located in zone B, indicating the hydrochemistry of this geothermal field is of the type $\mathrm{Na}-\mathrm{HCO}_{3}$. In contrast, hot springs in the Langjiu thermal were in zone A, indicating its hydrochemistry is of the type is $\mathrm{Na}-\mathrm{Cl}$. Surface waters from both fields occurred in zone $\mathrm{D}$, indicating their hydrochemistry is of the type Ca-Mg$\mathrm{HCO}_{3}$. The similarities in surface water hydrochemistry reflect similar surficial geology, but geothermal waters show distinct differences in subsurface geochemical conditions. There has been much deposition of silica sinters at Dagejia, but many travertines deposited in Langjiu, suggesting different water vapor sources or $\mathrm{CO}_{2}$ degassing mechanisms leading to the differing hydrochemistry and precipitated deposits.

\subsection{Ion sources}

Activity plots are a useful graphical tool to describe the stability of solids in relation to the composition of the coexistence solution [62]. In this study, a Na-K geothermometer was used to calculate the base reservoir temperature of the thermal field (Table 2). The temperature range of the two fields was $215.34-284.72^{\circ} \mathrm{C}$, and the mean was $251.36^{\circ} \mathrm{C}$,

Table 1 Hydrochemical data of the Dagejia and Langjiu thermal fields

\begin{tabular}{|c|c|c|c|c|c|c|c|c|c|c|c|c|c|c|}
\hline & \multirow{2}{*}{ No. } & \multirow{2}{*}{$\begin{array}{c}T \\
\left({ }^{\circ} \mathrm{C}\right)\end{array}$} & \multirow{2}{*}{$\mathrm{pH}$} & \multirow{2}{*}{$\begin{array}{c}\mathrm{EC} \\
\left(\mu \mathrm{S} \mathrm{cm}^{-1}\right)\end{array}$} & $\mathrm{Na}^{+}$ & $\mathrm{K}^{+}$ & $\mathrm{Ca}^{2+}$ & $\mathrm{Mg}^{2+}$ & $\mathrm{CO}_{3}^{2-}$ & $\mathrm{HCO}_{3}^{-}$ & $\mathrm{SO}_{4}^{2-}$ & $\mathrm{Cl}^{-}$ & $\mathrm{F}^{-}$ & $\mathrm{SiO}_{2}$ \\
\hline & & & & & \multicolumn{10}{|c|}{$\left(\mathrm{mg} \mathrm{L}^{-1}\right)$} \\
\hline \multirow{8}{*}{ 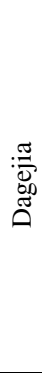 } & DJ1 & 81.2 & 7.75 & 1694 & 408.91 & 62.66 & 2.95 & - & - & 664.9 & 77.01 & 185.71 & 2.89 & 349.69 \\
\hline & DJ104 & 26.5 & 8.54 & 1582 & 280.6 & 33.7 & 1.38 & - & 108 & 500.2 & 67.6 & 174.06 & 3.81 & 249.87 \\
\hline & DJ106 & 23.3 & 8.16 & 1642 & 329.6 & 39 & 2.12 & 0.01 & - & 628.3 & 73.42 & 164.47 & 8.28 & 265.22 \\
\hline & DJ109 & 19.6 & 8.78 & 1703 & 339.8 & 41.89 & 1.48 & - & 198 & 451.4 & 80.37 & 171.32 & 0.01 & 317.12 \\
\hline & DJ112 & 30.3 & 8.57 & 1839 & 375.3 & 47.17 & 1.13 & - & 138 & 567.3 & 84.29 & 171.32 & 1.46 & 363.42 \\
\hline & DJ116 & 26.9 & 8.06 & 1848 & 348.4 & 42.53 & 1.09 & - & - & 719.8 & 84.69 & 185.03 & 6.43 & 337.27 \\
\hline & River $^{\text {a) }}$ & 11 & 7.4 & - & 4 & 0.5 & 12.8 & 1.46 & 0 & 55.5 & 8 & 2.5 & 0.44 & 4.4 \\
\hline & Lake & 9 & 8.43 & 118 & 16.7 & 1.2 & 10.3 & 1.7 & 0 & 97.6 & 12 & 2.08 & 0.57 & 2.4 \\
\hline \multirow{7}{*}{ : } & $\star \mathrm{LJ} 1$ & 99.3 & 7.71 & 2610 & 559.6 & 50.82 & 36.59 & 1.76 & - & 646.6 & 306.41 & 394.04 & 0 & 159.52 \\
\hline & $\star \mathrm{LJ} 2^{\mathrm{b})}$ & 91 & 8.15 & - & 595.8 & 65.91 & 32.04 & 3.32 & 111.7 & 403.63 & 327.63 & 399.06 & 7.8 & 175 \\
\hline & $\star \mathrm{LJ}^{\mathrm{b}}{ }^{\mathrm{b}}$ & 98 & 8.15 & - & 552.2 & 62.93 & 30.48 & 3.32 & 50.4 & 515.76 & 306.23 & 382.66 & 8.2 & 185 \\
\hline & $\star \mathrm{LJ}^{\mathrm{b})}$ & 105 & 8.2 & - & 576.6 & 63.02 & 27.75 & 2.13 & 3.15 & 611.68 & 348.19 & 382.18 & 8.8 & 174.63 \\
\hline & $\star \mathrm{LJ}^{6}{ }^{\mathrm{b})}$ & 102 & 8.15 & - & 605.2 & 66.95 & 34.39 & 1.66 & 37.8 & 573.41 & 332.57 & 386.32 & 8.8 & 185 \\
\hline & $\begin{array}{l}\text { Glacial- } \\
\text { water }\end{array}$ & 0 & 9.15 & 83 & 2.64 & 0.76 & 14.91 & 0.16 & 36 & 12.2 & 10.38 & 13.71 & 0.67 & 98.92 \\
\hline & $\begin{array}{l}\text { Langqu } \\
\text { River }\end{array}$ & 24 & 8.71 & 277 & 6.65 & 1.29 & 55.45 & 7.85 & 36 & 109.8 & 25.31 & 20.56 & 0 & 15 \\
\hline
\end{tabular}

a) From "Hot Springs Records in Tibet"; b) from the Chengdu University of Technology; $\star$ from drilling well data; River is water in Changma Stream and the Lake is the water from Dajiamang Lake. 


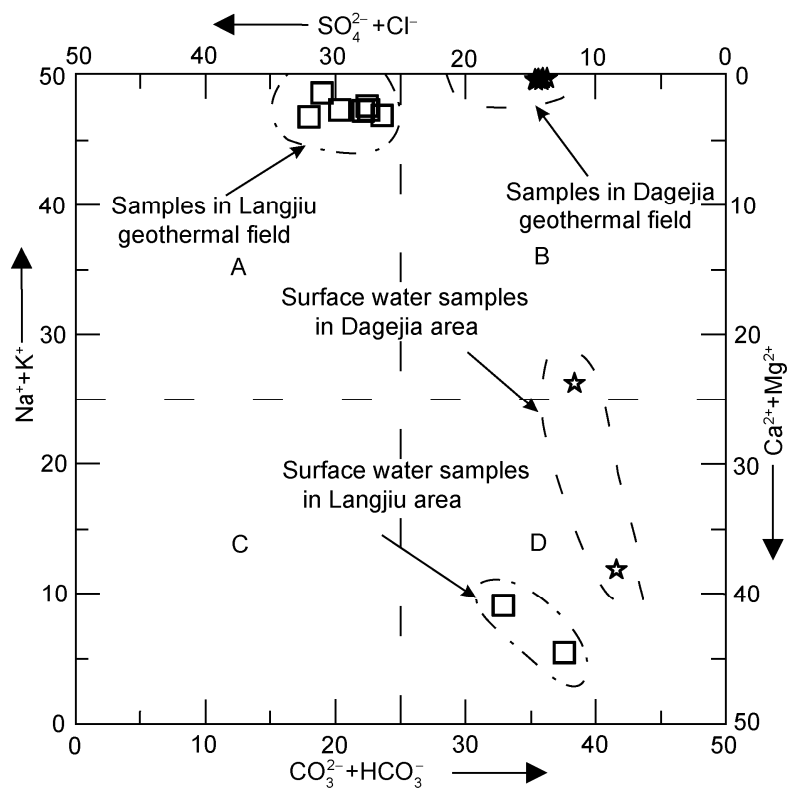

Figure 3 Hydrochemical classification of samples from the Langjiu and Dagejia geothermal fields.

which was chosen as the reference temperature for the activity diagram. This approach assumes coexistence of the vapor and liquid phases for a $\mathrm{H}_{2} \mathrm{O}$-dominated fluid in the system [63]. We plotted our sample data on activity diagrams of $\mathrm{Na}_{2} \mathrm{O}-\mathrm{Al}_{2} \mathrm{O}_{3}-\mathrm{SiO}_{2}-\mathrm{H}_{2} \mathrm{O}$ and $\mathrm{K}_{2} \mathrm{O}-\mathrm{Al}_{2} \mathrm{O}_{3}-\mathrm{SiO}_{2}-\mathrm{H}_{2} \mathrm{O}$ to characterize phase precipitation resulting from a heterogeneous solution of K-feldspar and albite [64]. Figure 4(a) shows the mineral phases albite, gibbsite, kaolinite and paragonite. Figure 4(b) shows the mineral phases K-feldspar,

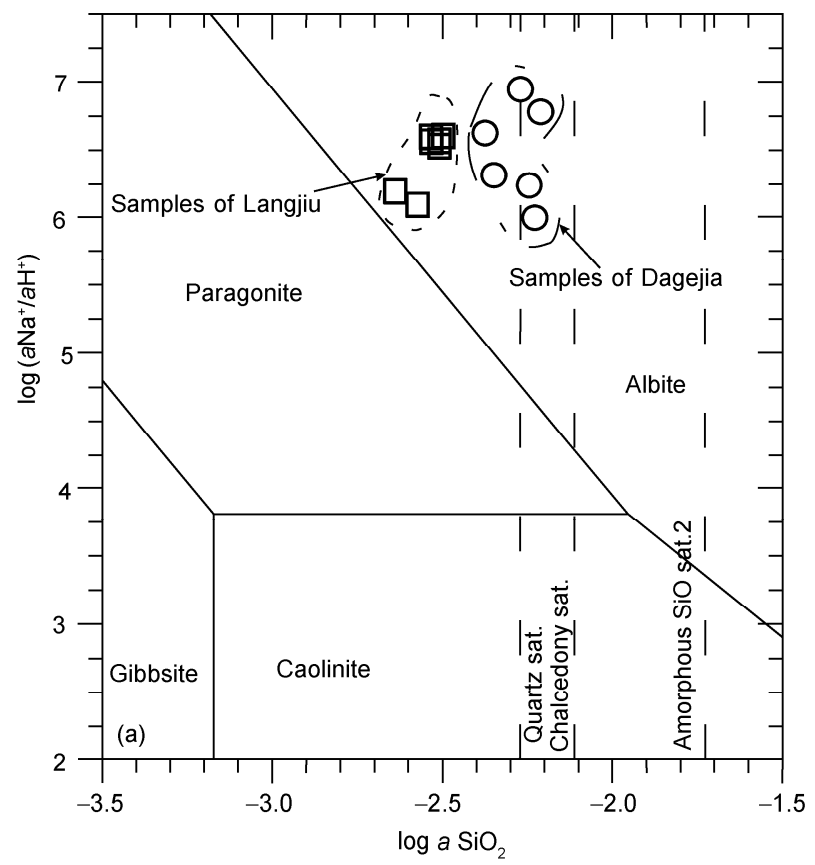

gibbsite, kaolinite and muscovite. Sample data show that $\mathrm{Na}^{+}$of geothermal water from both the Langjiu and Dagejia fields are determined by the albite, and the sample population is close to the quartz and chalcedony saturation lines (Figure 4(a)). The data also show that the activity of $\mathrm{K}^{+}$is controlled by K-feldspar (Figure 4(b)). Because both geothermal fields areas are underlain by intruded granites in which K-feldspar and albite are the major minerals, $\mathrm{K}^{+}$and $\mathrm{Na}^{+}$are likely the products of water-rock interactions between the thermal waters and granite.

\subsection{Carbon dioxide degassing from the geothermal fields}

(1) Carbon dioxide degassing. Gas analyses showed there were many geothermal gases emitted from both the Langjiu and Dagejia geothermal fields, of which $\mathrm{CO}_{2}$ was the main component. The calculation of a mineral saturation index (SI) can assist in determining the direction of chemical reactions in the geothermal waters, and indicates which reaction may occur with changes in temperature, pressure and redox during hydrothermal migration. For each sample from Langjiu and Dagejia we calculated the SI for typical minerals, $\mathrm{CO}_{2}$ partial pressure and total dissolved inorganic carbon (TDIC) (Table 2). The SI, fractional pressure and TDIC were calculated using the PHREEQC model [64]. We used Can's $\mathrm{Na} / \mathrm{K}$ equation to calculate a geothermometer $\left(T_{\mathrm{N}-\mathrm{K}}\right)$ [65], the normalized mean square error of which was $0.179^{\circ} \mathrm{C}$.

The magnitude of TDIC was similar to the measured values. The SI of calcite, dolomite and aragonite in the Langjiu

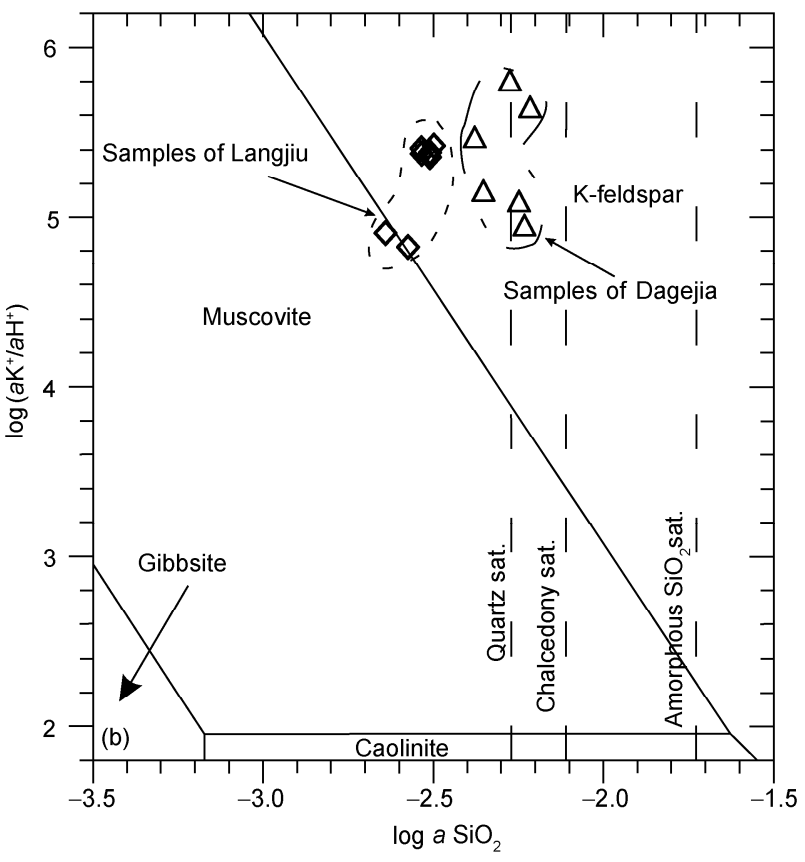

Figure 4 Activity plots for the geothermal water samples of study areas. (a) $\mathrm{Na}_{2} \mathrm{O}-\mathrm{Al}_{2} \mathrm{O}_{3}-\mathrm{SiO}_{2}-\mathrm{H}_{2} \mathrm{O}$; (b) $\mathrm{K}_{2} \mathrm{O}-\mathrm{Al}_{2} \mathrm{O}_{3}-\mathrm{SiO}_{2}-\mathrm{H}_{2} \mathrm{O}$. 
Table 2 Calculated saturation indices for typical minerals, $\mathrm{CO}_{2}$ partial pressure, total dissolved inorganic carbon (TDIC) and equilibrium temperature of geothermal reservoir $\left(T_{\mathrm{N}-\mathrm{K}}\right)^{\mathrm{a})}$

\begin{tabular}{lcccccccccccc}
\hline & DJ1 & DJ104 & DJ106 & DJ109 & DJ112 & DJ116 & LJ1 & LJ2 & LJ3 & LJ4 & LJ5 & LJ6 \\
\hline SI Aragonite & -0.06 & -0.28 & -0.48 & -0.12 & -0.27 & -0.77 & 1.21 & 0.9 & 1.29 & 1.31 & 1.41 & 1.09 \\
SI Calcite & 0.05 & -0.14 & -0.33 & 0.03 & -0.13 & -0.63 & 1.31 & 1.01 & 1.39 & 1.41 & 1.51 & 1.19 \\
SI Dolomite & -2.96 & -3.03 & -2.62 & -2.81 & -2.87 & -3.92 & 1.88 & 1.26 & 1.97 & 1.83 & 1.74 & 1.15 \\
SI Gypsum & -3.17 & -3.58 & -3.34 & -3.51 & -3.64 & -3.59 & -1.68 & -1.94 & -1.72 & -1.73 & -1.64 & -1.57 \\
SI Anhydrite & -2.93 & -3.8 & -3.57 & -3.75 & -3.84 & -3.81 & -1.32 & -1.56 & -1.27 & -1.26 & -1.1 & -1.11 \\
SI Chalcedony & 0.75 & 1.13 & 1.21 & 1.31 & 1.24 & 1.27 & 0.34 & 0.36 & 0.31 & 0.26 & 0.25 & 0.27 \\
SI Quartz & 1.04 & 1.55 & 1.64 & 1.75 & 1.66 & 1.7 & 0.6 & 0.61 & 0.56 & 0.5 & 0.49 & 0.51 \\
SI SiO ${ }_{2}(\mathrm{a})$ & 0.07 & 0.3 & 0.36 & 0.45 & 0.42 & 0.44 & -0.31 & -0.3 & -0.33 & -0.38 & -0.37 & -0.37 \\
SI Chrysotile & -7.61 & -8.63 & -8.06 & -7.91 & -7.78 & -11.18 & 4.95 & 4.44 & 5.5 & 5.2 & 5.01 & 2.14 \\
SI Sepiolite & -5.8 & -4.14 & -3.51 & -3.11 & -3.52 & -5.61 & 1.63 & 1.26 & 1.76 & 1.43 & 1.17 & -0.58 \\
SI Talc & -1.81 & -2.65 & -1.97 & -1.68 & -1.52 & -4.91 & 10 & 9.53 & 10.53 & 10.15 & 9.98 & 7.1 \\
SI Fluorite & -2.09 & -1.71 & -0.79 & -8.79 & -2.73 & -1.36 & -0.88 & -0.75 & -0.43 & -0.46 & -0.37 & -4.12 \\
SI Halite & -5.86 & -5.92 & -5.87 & -5.83 & -5.82 & -5.81 & -5.38 & -5.45 & -5.48 & -5.47 & -5.46 & -5.46 \\
$\log P_{\mathrm{CO}_{2}}$ & -1.55 & -2.78 & -2.4 & -3.04 & -2.73 & -2.23 & -2.03 & -2.08 & -1.93 & -1.93 & -1.85 & -1.39 \\
$\log P_{\mathrm{CO}_{2}\left(190^{\circ} \mathrm{C}\right)}$ & -0.7 & -1.53 & -1.11 & -1.8 & -1.53 & -0.95 & -1.26 & -1.33 & -1.21 & -1.23 & -1.18 & -0.7 \\
TDIC (mg L ${ }^{-1}$ ) & 130.83 & 119.59 & 123.52 & 127.71 & 138.73 & 141.61 & 101.35 & 95.48 & 111.34 & 120.94 & 120.22 & 130.76 \\
$T_{\mathrm{N}-\mathrm{K}\left({ }^{\circ} \mathrm{C}\right)}$ & 284.72 & 255.88 & 254.41 & 258.95 & 261.15 & 257.76 & 213.97 & 214.74 & 216.64 & 212.89 & 213.97 & 197.3 \\
\hline
\end{tabular}

a) DJ, Dagejia field. LJ, Langjiu.

geothermal field was above one, which indicates a high degree of supersaturation and conditions favorable to mineral precipitation. The degree of quartz and chalcedony supersaturation was lower than that of calcite, dolomite and aragonite, so there are few siliceous sinter precipitates. The SI of calcite, dolomite and aragonite in the Dagejia geothermal field is negative, indicating unsaturated conditions that are unfavorable to precipitation, reflecting the lack of travertine sediments in this area. However, the saturation of quartz and chalcedony was above zero, reflecting the significant and widespread siliceous sinter sediments in this area.

We used the $\mathrm{HCO}_{3}^{-}-P_{\mathrm{CO}_{2}}$ model deduced from the calcite, dolomite, anhydrite and fluorite equilibrium reaction system to simulate theoretical $\mathrm{HCO}_{3}^{-}-P_{\mathrm{CO}_{2}}$ curves [19]:

$$
\begin{aligned}
\log m_{\mathrm{HCO}_{3}}= & -4.819+0.457 \log P_{\mathrm{CO}_{2}} \\
& +970.29 / \mathrm{T}+0.07323 \log \Sigma \text { eq. }
\end{aligned}
$$

In both geothermal fields, at simulated temperature of $190^{\circ} \mathrm{C}$ the $P_{\mathrm{CO}_{2}}$ of deep thermal water was higher than that at the vents (Figure 5). The modeled $P_{\mathrm{CO}_{2}}$ trended toward $\mathrm{CO}_{2}$ degassing during thermal water migration from the deep reservoir to the surface, and this is inferred to be what is happening in the Langjiu and Dagejia geothermal fields.

(2) Degassing mechanisms and associated precipitation of siliceous sinter and travertine. Two study areas are both located within the Gangdisê-Nyainqêntanglha microplate, and the large regional geothermal anomalies are controlled by the Gangdisê continental margin magmatic arc. The main sources of geothermal water $\mathrm{CO}_{2}$ are magma degassing and products of hydrothermal alternation due to magmatism. The following series of equations described the evolution of $\mathrm{CO}_{2}$ from primary and altered (clay) silicate minerals:

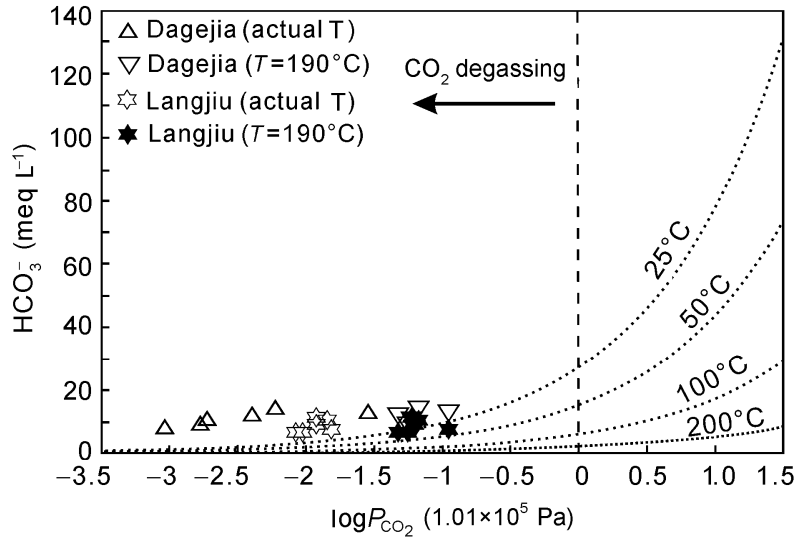

Figure 5 Measures and modeled and $\mathrm{HCO}_{3}^{-}-P_{\mathrm{CO}_{2}}$ of geothermal waters at the Langjiu and Dagejia geothermal fields.

$$
\begin{gathered}
6 \mathrm{~K}\left[\mathrm{AlSi}_{3} \mathrm{O}_{8}\right]_{(\mathrm{K} \text {-feldspar) }}+2 \mathrm{H}_{2} \mathrm{O}+2 \mathrm{CO}_{2} \\
=\mathrm{K}_{2} \mathrm{Al}_{4}\left[\mathrm{Al}_{2} \mathrm{Si}_{6} \mathrm{O}_{20}\right](\mathrm{OH})_{4 \text { (muscovite) }}+12 \mathrm{SiO}_{2}+2 \mathrm{~K}_{2} \mathrm{CO}_{3} \\
4 \mathrm{~K}\left[\mathrm{AlSi}_{3} \mathrm{O}_{8}\right]_{(\mathrm{K} \text {-feldspar) }}+4 \mathrm{H}_{2} \mathrm{O}+2 \mathrm{CO}_{2} \\
=\mathrm{Al}_{4}\left[\mathrm{Si}_{4} \mathrm{O}_{10}\right](\mathrm{OH})_{8 \text { (caolinite) }}+8 \mathrm{SiO}_{2}+2 \mathrm{~K}_{2} \mathrm{CO}_{3} \\
\mathrm{CaCO}_{3 \text { (calcite) }}+\mathrm{SiO}_{2}=\mathrm{CaSiO}_{3 \text { (wollastonite) }}+\mathrm{CO}_{2} \uparrow \\
\mathrm{MgCa}\left(\mathrm{CO}_{3}\right)_{2 \text { (dolomite) }}+2 \mathrm{SiO}_{2} \\
=\mathrm{CaMg}\left(\mathrm{SiO}_{3}\right)_{2 \text { (diopside) }}+2 \mathrm{CO}_{2} \uparrow \\
\mathrm{CaCO}_{3 \text { (calcite, aragonite) }}+\mathrm{CO}_{2}+\mathrm{H}_{2} \mathrm{O} \Leftrightarrow \mathrm{Ca}^{2+}+2 \mathrm{HCO}_{3}^{-} \\
\mathrm{Ca}^{2+}+2 \mathrm{HCO}_{3}^{-} \Leftrightarrow \mathrm{CaCO}_{3} \downarrow+\mathrm{H}_{2} \mathrm{O}+\mathrm{CO}_{2} \uparrow \\
\mathrm{K}_{2} \mathrm{CO}_{3}+\mathrm{H}^{+}=\mathrm{K}^{+}+\mathrm{H}_{2} \mathrm{O}+\mathrm{CO}_{2} \uparrow
\end{gathered}
$$

The different geological conditions between the two study areas mean that the reactions that occur during hydrothermal also differ (Figure 6). At Langjiu, the $\mathrm{SiO}_{2}$ produced by magmatic hydrothermal alteration reacts with K-feldspar, 
and albite reacts with carbonate and generates wollastonite, with resulting $\mathrm{CO}_{2}$ degassing. While a fraction of $\mathrm{CO}_{2}$ escapes to the atmosphere through fissures, the remainder reacts with the carbonate of wall rocks to generate $\mathrm{HCO}_{3}^{-}$. Pressure reduces rapidly when the geothermal water reaches the surface, releasing $\mathrm{CO}_{2}$ from solution. Travertine precipitates simultaneously from the solution at the surface. At Dagejia low-permeability clastic rocks are widespread, and comprise an effective impermeable layer as roof rock. The $\mathrm{SiO}_{2}$ produced by hydrothermally altered K-feldspar and albite does not react with the wall rocks, but instead migrates in solution with the geothermal water to the surface and precipitates as siliceous sinter sediments due to the drop in temperature and pressure. The hydrothermally produced $\mathrm{K}_{2} \mathrm{CO}_{3}$, and $\mathrm{Na}_{2} \mathrm{CO}_{3}$ under the ambient low-pH conditions release $\mathrm{CO}_{2}$, some of which forms $\mathrm{HCO}_{3}^{-}$and $\mathrm{CO}_{3}^{2-}$, leading to the high concentrations of these species at Dagejia.

(3) Calculating $\mathrm{CO}_{2}$ degassing flux. Based on the $\mathrm{CO}_{2}$ degassing mechanisms determined for the Langjiu and Dagejia geothermal fields, we calculated the $\mathrm{CO}_{2}$ degassing flux from both. Total $\mathrm{CO}_{2}$ degassing flux is composed of $\mathrm{CO}_{2}$ released from solution during geothermal water upwelling and $\mathrm{CO}_{2}$ evolved from chemical reactions and interface effects subsequent to geothermal water arrival at the surface [35]. Therefore total $\mathrm{CO}_{2}$ flux $(J)$ in the study areas consisted of

$$
J=J_{1}+J_{2}+J_{3} \text {, }
$$

where $J_{1}$ is $\mathrm{CO}_{2}$ diffusion flux at vents, $J_{2}$ is $\mathrm{CO}_{2}$ degassing flux during travertine precipitation, and $J_{3}$ is $\mathrm{CO}_{2}$ degassing flux from solution during geothermal water discharge in the sinter deposition zone.

The $\mathrm{CO}_{2}$ concentrations at vents and in the ambient atmosphere different significantly, which will lead to bulk gas flow. Therefore $\mathrm{CO}_{2}$ diffusion flux at vents $\left(J_{1}\right)$ can be calculated by Fick's first law [66]:

$$
J_{1}=-D \frac{\mathrm{d} C}{\mathrm{~d} x},
$$

where $D$ is the diffusion coefficient $\left(\mathrm{cm}^{2} \mathrm{~s}^{-1}\right), C$ is mass concentration of diffused molecules $\left(\mathrm{g} \mathrm{cm}^{-3}\right), \mathrm{d} C / \mathrm{d} x$ is the concentration gradient of diffused molecules in direction $x$ $\left(\mathrm{g} \mathrm{cm}^{-4}\right)$, and the minus symbol indicates means downgradient diffusion.

The Langjiu and Dagejia geothermal fields are at altitudes of $4500 \mathrm{~m}$ and $5100 \mathrm{~m}$, respectively, and the mean annual temperature at both areas is $\sim 0^{\circ} \mathrm{C}$. The $\mathrm{CO}_{2}$ concentration of local atmosphere was surveyed at the distance of 1,2 and $10 \mathrm{~m}$ with infrared carbon dioxide analyzer. Substituting the measured $\mathrm{CO}_{2}$ concentrations and the diffusion coefficient $(D)$ of $\mathrm{CO}_{2}$ in air $\left(0.016 \mathrm{~cm}^{2} \mathrm{~s}^{-1}\right.$ [67-69]) into eq. (10), we calculated the $\mathrm{CO}_{2}$ diffusion flux by integration (Table 3).

At the Langjiu geothermal field, $\mathrm{CO}_{2}$ degassing during travertine precipitation $\left(J_{2}\right)$ is calculated as

$$
J_{2}=S \cdot h / n \cdot \rho / M_{1} \cdot M_{2} / S_{\mathrm{t}}
$$

where $S$ is spatial extent of the travertine precipitation $\left(\mathrm{m}^{2}\right)$,

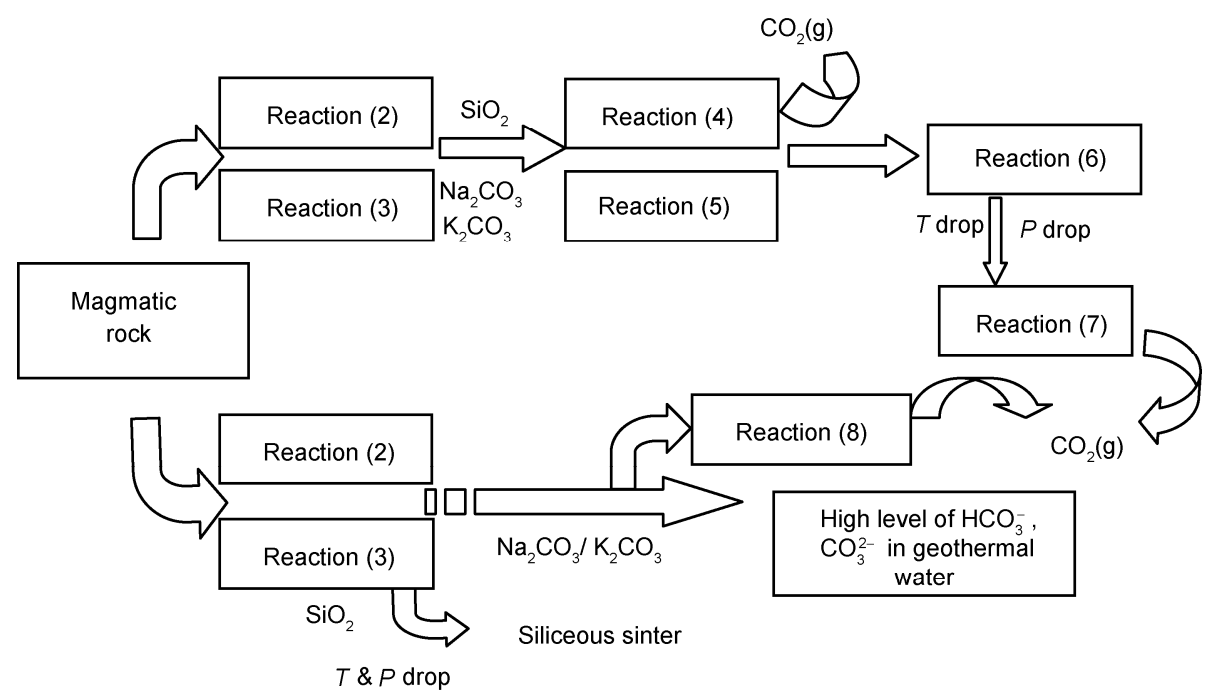

Figure 6 Conceptual model of two hydrogeothermal $\mathrm{CO}_{2}$ degassing reaction pathways. The upper pathway is typical of the Langjiu geothermal field, and

\begin{tabular}{|c|c|c|c|c|c|}
\hline Study areas & Initial concentration $\left(\mathrm{g} \mathrm{L}^{-1}\right)$ & Concentration at $1 \mathrm{~m}\left(\mathrm{~g} \mathrm{~L}^{-1}\right)$ & Concentration at $2 \mathrm{~m}\left(\mathrm{~g} \mathrm{~L}^{-1}\right)$ & Concentration at $10 \mathrm{~m}\left(\mathrm{~g} \mathrm{~L}^{-1}\right)$ & $\begin{array}{c}\text { Diffusion flux } \\
\left(\times 10^{3} \mathrm{~kg} \mathrm{~km}^{-2} \mathrm{a}^{-1}\right)\end{array}$ \\
\hline Langjiu & $5.30 \times 10^{-4}$ & $5.01 \times 10^{-4}$ & $4.60 \times 10^{-4}$ & $2.21 \times 10^{-4}$ & 15.60 \\
\hline Dagejia & $10.21 \times 10^{-4}$ & $9.38 \times 10^{-4}$ & $8.56 \times 10^{-4}$ & $2.05 \times 10^{-4}$ & 41.20 \\
\hline
\end{tabular}
the lower pathway is typical of the Dagejia geothermal field. (2)-(8) refer to reaction equations described in the text.

Table 3 Calculated $\mathrm{CO}_{2}$ diffusion fluxes from vents at the Langjiu and Dagejia geothermal fields 
Table 4 Calculation of $\mathrm{CO}_{2}$ degassing flux when water-air balance

\begin{tabular}{ccccc}
\hline Study areas & $P_{\mathrm{CO}_{2}}$ of geothermal water $(\mathrm{Pa})$ & $P_{\mathrm{CO}_{2}}$ of local atmosphere $(\mathrm{Pa})$ & $Q\left(\mathrm{~L} \mathrm{~s}^{-1}\right)$ & $\mathrm{CO}_{2}$ degassing flux $\left(J_{3}\right)\left(\times 10^{3} \mathrm{~kg} \mathrm{~km}^{-2} \mathrm{a}^{-1}\right)$ \\
\hline Langjiu & 9843.21 & 170.83 & 10 & 3142.20 \\
Dagejia & 7151.98 & 158.47 & 15 & 3308.21 \\
\hline
\end{tabular}

$h$ is travertine thickness (m), $n$ is time of deposition (age in years), $\rho$ is travertine density of $\left(\mathrm{kg} \mathrm{m}^{-3}\right), M_{1}$ is $\mathrm{CaCO}_{3}$ molar mass $\left(\mathrm{g} \mathrm{mol}^{-1}\right), M_{2}$ is $\mathrm{CO}_{2}$ molar mass $\left(\mathrm{g} \mathrm{mol}^{-1}\right)$, and $S_{\mathrm{t}}$ is spatial extent of the geothermal field $\left(\mathrm{km}^{2}\right)$.

Since 1984 there has been extensive drilling conducted in the Langjiu geothermal field, and the thickness of travertine in the abandoned casings is $\sim 6 \mathrm{~cm}$ (Figure 2(c)). Therefore substituting into eq. (3) $h=0.06 \mathrm{~m}, n=25 \mathrm{a}, S=40000 \mathrm{~m}^{2}$, and $\rho=$ $2710 \mathrm{~kg} \mathrm{~m}^{-3}$, we derive $J_{2}=476.94 \times 10^{3} \mathrm{~kg} \mathrm{~km}^{-2} \mathrm{a}^{-1}$.

The $\mathrm{CO}_{2}$ degassing flux during geothermal surface water flows $\left(J_{3}\right)$ in study areas was calculated as

$$
J_{3}=\left(P_{0}-P x\right) \times Q / 10^{6},
$$

where $P_{0}$ is the $\mathrm{CO}_{2}$ partial pressure in geothermal water at the vents $(\mathrm{Pa}), P x$ is the $\mathrm{CO}_{2}$ partial pressure of the local atmosphere $(\mathrm{Pa})$, and $Q$ is the rate of geothermal water flow $\left(\mathrm{L} \mathrm{s}^{-1}\right)$. Calculated fluxes are presented in Table 4 .

By substituting eqs. (10)-(12) into eq. (9), the total $\mathrm{CO}_{2}$ flux from the Langjiu and Dagejia geothermal fields is $J_{\text {Langiu }}=3.63476 \times 10^{6} \mathrm{~kg} \mathrm{~km}^{-2} \mathrm{a}^{-1}$ and $J_{\text {Dagejia }}=3.34941 \times 10^{6} \mathrm{~kg}$ $\mathrm{km}^{-2} \mathrm{a}^{-1}$

\section{Conclusions}

By characterizing the geological environment, water and gases at both the Langjiu and Dagejia geothermal fields, we conclude the following:

(1) Both the Langjiu and Dagejia geothermal fields are located in the Gangdisê-Nyainqêntanglha plate, and high geothermal anomalies manifested in this region are controlled by the Gangdisê continental margin magmatic arc. The chemistry of geothermal waters in both fields is controlled by K-feldspar and albite. The water types of the two geothermal fields differ, with Langjiu characterized as $\mathrm{Na}-\mathrm{Cl}$ type and Dagejia characterized as $\mathrm{Na}-\mathrm{HCO}_{3}$ type. This suggests that the chemical reactions during geothermal water migration to the surface are different.

(2) The saturation index of typical minerals and $P_{\mathrm{CO}_{2}}$ of geothermal water in both geothermal fields shows $\mathrm{CO}_{2}$ degassing during the processes of geothermal water ascensions to the surface. However, the products of $\mathrm{CO}_{2}$ degassing and chemical reactions in two geothermal fields differ due to their different geological settings.

(3) Different mechanisms of $\mathrm{CO}_{2}$ degassing in Langjiu geothermal field and Dagejia geothermal field were studied and the different calculation formulas of $\mathrm{CO}_{2}$ degassing quantity are acquired. Through the calculation formulas, $\mathrm{CO}_{2}$ degassing fluxes from the Langjiu geothermal field and
Dagejia geothermal field were estimated to be $\sim 3.6 \times 10^{6} \mathrm{~kg}$ $\mathrm{km}^{-2} \mathrm{a}^{-1}$ and $\sim 3.3 \times 10^{6} \mathrm{~kg} \mathrm{~km}^{-2} \mathrm{a}^{-1}$ respectively.

We are thankful to Dr. Pu Junbing, Dr. Sun Yuchuan and the teachers and students in the Geochemistry and Isotope Laboratory of the School of Geographical Science. We thank Zhou Le at the College of Mathematics and Statistics, Southwest University, China, and Yao Dan at the University of Bristol, UK. We would also like to acknowledge several reviewers for their critical reviews of the manuscript and suggestions for further improvements. This work was supported by the Fundamental Research Funds for the Central Universities (XDJK2010B006), Ministry of Science and Technology International Cooperation Project (2008GR1256), the National Natural Science Foundation of China (41072192); the Doctoral Program of Higher Education Research Fund (20100182120029 and 200806350008), the Foundation Southwest University Ph.D. (SWUB2008013), and the Graduate Innovation Fund of Southwest University (KY2010002 and KB2009004).

1 Yuan D X. Carbon cycle in earth system and its effects on environment and resources (in Chinese). Quat Sci, 2001, 21: 223-233

2 Kerrick D M, McKibben M A, Seward T M, et al. Convective hydrothermal $\mathrm{CO}_{2}$ emission from high heat flow regions. Chem Geol, 1995, 121: 285-293

3 Evans M J, Derry L A, France-Lanord C. Degassing of metamorphic carbon dioxide from the Nepal Himalaya. Geochem Geophys Geosyst, 2008, 9: Q04021, doi:10.1029/2007GC001796

4 Gaillardet J, Galy A. Himalaya-Carbon Sink or Source? Science, 2008, 320: 1727-1728

5 Becker J A, Bickle M J, Galy A, et al. Himalayan metamorphic $\mathrm{CO}_{2}$ fluxes: Quantitative constraints from hydrothermal springs. Earth Planet Sci Lett, 2008, 265: 616-629

6 Oppo D. Millennial climate oscillations. Science, 1997, 278: 12441246

7 Berner R A, Lasaga A C. Garrels R M. The carbonate-silicate geochemical cycle and its effect on atmospheric carbon dioxide over the past 100 million years. Am J Sci, 1983, 283: 641-683

8 Kerrick D M, Caldeira K. Metamorphic $\mathrm{CO}_{2}$ degassing from orogenic belts. Chem Geol, 1998, 145: 213-232

9 Kerrick D M, Caldeira K. Was the Himalayan orogen a climatically significant coupled source and sink for atmospheric $\mathrm{CO}_{2}$ during the Cenozoic? Earth Planet Sci Lett, 1999, 173, 195-203

10 Allard P, Carbonelle J, Dajlevic D, et al. Eruptive and diffuse emissions of $\mathrm{CO}_{2}$ from Mount Etna. Nature, 1991, 351: 387-391

11 Brantley, S L, Koepenick K W. Measured carbon-dioxide emissions from Oldoinyo-Lengai and the skewed distribution of passive volcanic fluxes. Geology, 1995, 23: 933-936

12 Seward T M, Kerrick D M. Hydrothermal $\mathrm{CO}_{2}$ emission from the Taupo Volcanic zone, New Zealand. Earth Planet Sci Lett, 1996, 139: 105-113

13 Marty B, Tolstikhin I N. $\mathrm{CO}_{2}$ fluxes from mid-ocean ridges, arcs and plumes. Chem Geol, 1998, 145: 233-248

14 Mörner N A, Etiope G. Carbon degassing from the lithosphere. Glob Planet Change, 2002, 33: 185-203

15 Frondini B, Cardellini C, Chiodini G, et al. Fluxes of deep $\mathrm{CO}_{2}$ in the volcanic areas of central-southern Italy. J Volcanol Geotherm Res, 2004, 136: 31-52, doi:10.1016/j.jvolgeores

16 Liu Z H, Yuan D X, He S Y, et al. Geochemical features and sources of $\mathrm{CO}_{2}$ of Geothermic $\mathrm{CO}_{2}^{-}$-Water-Carbonate system-In cases of Huanglong Valley, Kangding, Sichuan and Zhongdian, Xiagei, Yun- 
nan (in Chinese). Sci China Ser D-Earth Sci, 2000, 30: 209-214

17 Chiodini G. Temperature, pressure and redox conditions governing the composition of the cold $\mathrm{CO}_{2}$ gases discharged in North Latium (Italy). Appl Geochem, 1994, 9: 287-295

18 Chiodini G, Frondini F. Carbon dioxide degassing from the Albani Hills volcanic region, central Italy. Chem Geol, 2001, 177: 67-83

19 Chiodini G, Frondini F, Marini L. Theoretical geothermometers and $P_{\mathrm{CO}_{2}}$ indicators for aqueous solutions coming from hydrothermal systems of medium-low temperature hosted in carbonate-evaporite rocks. Applications to the thermal springs of the Etruscan Swell, Italy. Appl Geochem, 1995, 10: 337-346

20 Chiodini G, Frondini F, Ponziani F. Deep structures and carbon dioxide degassing in central Italy. Geothermics, 1995, 24: 81-94

21 Chiodini G, Cioni R, Guidi M, et al. Soil $\mathrm{CO}_{2}$ flux measurements in volcanic and geothermal areas. Appl Geochem, 1998, 13: 543-552

22 Chiodini G, Frondini F, Kerrick D M, et al. Quantification of deep $\mathrm{CO}_{2}$ fluxes from central Italy. Examples of carbon balance for regional aquifers and of soil diffuse degassing. Chem Geol, 1999, 159: 205222

23 Chiodini G, Frondini F, Cardellini C, et al. Rate of diffuse carbon dioxide earth degassing estimated from carbon balance of regional aquifers: The case of central Apennine, Italy. J Geophys Res, 2000, 105: 8423-8434

24 Chiodini G, Cardellini C, Amato A, et al. Carbon dioxide Earth degassing and seismogenesis in central and southern Italy. Geophys Res Lett, 2004, 31, doi:10.1029/2004GL019480

25 Allard P. A CO $\mathrm{CO}_{2}$-rich gas trigger of explosive paroxysms as Stromboli basaltic volcano, Italy. J Volcanol Geoth Res, 2010, 189: 343-374

26 Frondini F, Caliro S, Cardellini C, et al. Carbon dioxide degassing and thermal energy release in the Monte Amiata volcanic-geothermal area (Italy). Appl Geochem, 2009, 24: 860-875

27 Prondini F, Caliro S, Carrdellini C, et al. Carbon dioxide degassing from Tuscany and Northern Latium (Italy). Glob Planet Change. 2008, 61: 89-102

28 Mayo A L, Muller A B. Low temperature diagenetic-metamorphic and magmatic contributions of external $\mathrm{CO}_{2}$ gas to a shallow groundwater system. J Hydrol, 1997, 194: 286-304

29 Nesbitt B E, Mendoza C A, Kerrick D M. Surface fluid convection during Cordilleran extension and the generation of metamorphic $\mathrm{CO}_{2}$ contributions to Cenozoic atmosphere. Geology, 1995, 23: 99-101

30 Kerrick D M, Caldeira K. Metamorphic $\mathrm{CO}_{2}$ degassing and Early Cenozoic paleoclimate. GSA Today, 1994, 4: 57-65

31 Pentecost A. Geochemistry of carbon dioxide in six Travertinedepositing. waters of Italy. J Hydrol, 1995, 167: 263-278

32 Arthaud F, Dazy J, Grillot J C. Distribution of deep carbon dioxide in relation to the structure and tectonic evolution of South-East France. Geodin Acta, 1994, 7: 86-102

33 Dai J X, Dai C S, Song Y. Geochemical characteristics and components of carbon and helium isotope of hot spring natural gases in some parts of China (in Chinese). Sci Chin Ser B, 1994, 24: 426-433

34 Dai J X, Song Y, Dai C S. Abiogenic Gas and Conditions of Its Gas Reservoir Formation in Eastern China (in Chinese). Beijing: Science Press, 1995. 1-212

35 Liu Z H, Dreybrodt W. Dissolutional kinetics of calcium carbonate minerals in $\mathrm{H}_{2} \mathrm{O}-\mathrm{CO}_{2}$ solutions in turbulent now: The role of the diffusion boundary layer and the slow reaction $\mathrm{H}_{2} \mathrm{O}+\mathrm{CO}_{2}=\mathrm{H}^{+}+\mathrm{HCO}_{3}^{-}$. Geochim Cosmochim Acta, 1997, 61: 2879-2889

36 Shangguan Z G, Liu G F, Gao S S. The $\mathrm{CO}_{2}$ discharges and sources in the area of the boundary faults of the Sichuan-Yunnan block (in Chinese). EQ Res Chin, 1993, 9: 146-153

37 Shangguan $\mathrm{Z}$ G, Huo W G. $\delta$ D values of escaped $\mathrm{H}_{2}$ from hot springs at the Tengchong Rehai geothermal area and its origin (in Chinese). Chinese Sci Bull, 2002, 47: 146-149

38 Shangguan Z G, Bai C H, Sun M L. Mantle-derived magmatic gas releasing features at the Rehai area, Tengchong County, Yunnan Province, China (in Chinese). Sci Chin Ser D-Earth Sci, 2000, 43: $132-140$

39 Zhao P, Xie E J, Duo J, et al. Geochemical characteristics of geothermal gases and their geological implications in Tibet (in Chinese).
Acta Petrol Sin, 2002, 18: 539-550

40 Shen L C, Yuan D X, Ding T P, et al. Distributing inhomogeneity of helium isotope of $\mathrm{CO}_{2}$ degasification point and its geotectogenesis in Southwest of China (in Chinese). Acta Geol Sin, 2007, 81: 475- 487

41 Tank V, Pfanz H, Kick H. New remote sensing techniques for the detection and quantification of earth surface $\mathrm{CO}_{2}$ degassing. J Volcanol Geoth Res, 2008, 177: 515-524

42 Williams H, Turner S, Kelley S, et al. Age and composition of dikes in Southern Tibet: New constraints on the timing of east-west extension and it's relationship to post-collisional volcanism. Geology, 2001, 29: 339-342

43 Blisniuk P M, Hacker B R, Glodny J, et al. Normal faulting in central Tibet since at least 13.5 Myr ago. Nature, 2001, 412: 628-632

44 Coleman M, Hodges K. Evidence for Tibetan plateau up lift before $14 \mathrm{Myr}$ ago from a new minimum age for east-west extension. Nature, 1995, 374: 49-52

45 Bllsnluk P M, Hacker B, Glodny J, et al. Normal faulting in central Tibet since at least 13.5 Myr ago. Nature, 2001, 412: 628-632

46 Zhang J, Ma Z J. East-West segmentation of the Tibetan Plateau and its implication (in Chinese). Acta Geol Sin, 2004, 78: 218-227

47 Li Z Q, Hou Z Q, Nie F J, et al. Characteristic and distribution of the partial melting layers in the upper crust: Evidence from active hydrothermal fluid in the south Tibet (in Chinese). Acta Geol Sin, 2005, 79: 68-77

48 Tibetan Plateau Comprehensive Scientific Expedition Team (CAS), Geothermal in Tibet (in Chinese). Beijing: Science Press, 1981. 130140

49 Tong W, Liao Z J, Liu S B, et al. Tibetan Hotspring Blog (in Chinese). Beijing: Science Press, 2000. 4-49

50 Liao Z L, Liao G Y, Pan G T, et al. Distribution and utilization of geothermal resources in Tibet Ngari (in Chinese). Chin Min Mag, 2005, 14: $43-46$

51 Tibet Bureau of Geology and Mineral Resources. Regional Geology Log of Tibet Autonomous Region. Geological Report of Ministry of Geology and Mineral Resources of People's Republic of China, NO.31 (in Chinese). Beijing: Geological Publishing House, 1993. 7-477

52 Pan G T, Ding J, Wang L Q, et al. Instructions of 1:1500000 Geological Map of Qinghai-Tibet Plateau and Adjacent Areas (in Chinese). Chengdu: Chengdu Cartograph Publishing House, 2004

53 Zhu D C, Mo X X, Wang L Q, et al. Petrogenesis of highly fractionated I-type granites in the Zayu area of eastern Gangdese, Tibet: Constraints from zircon U-Pb geochronology, geochemistry and Sr-Nd-Hf isotopes. Sci Chin Ser D-Earth Sci, 2009, 52: 1223-1239

54 Zhao Y Y, Nie F J, Hou Z Q, et al. Geological characteristics and formation age of hot spring cesium deposit in Targejia area, Tibet (in Chinese). Mineral Deposits, 2006, 25: 281-291

55 Zhao Y Y, Nie F J, Hou Z Q, et al. Isotope characteristics and formation process of hot spring type cesium deposit in Targejia, Tibet (in Chinese). Miner Deposits, 2006, 25: 613-619

56 Zhao Y Y, Zhao X T, Ma Z B. Study on Chronology for hot spring typed Cs-deposit of Targejia, Tibet (in Chinese). Acta Petrol Sin, 2006, 22: 717-724

57 Zhao Y Y, Nie F J, Hou Z Q, et al. Geochemistry of Targria hot spring type cesium deposit in Tibet (in Chinese). Miner Deposits, 2007, 25: 163-174

58 Zheng M P, Wang Q X, Duo J, et al. New Types of Hydrothermal Mineralization - Cesium Silicon Sinter Deposits in Tibet (in Chinese). Beijing: Geological Publishing House, 1995. 1-110

59 Hou Z Q, Li Z Q. Possible location for underthrusting front of the Indus Continent: Constraints from Helium Isotope of the Geothermal Gas in Southern Tibet and Eastern Tibet (in Chinese). Acta Geol Sin, 2004, 78: 482-493

60 Gupta H, Roy S. Geothermal Energy: An Alternative Resource for the 21st Century. Elsevier, 2007. 121-164

61 Fytikas M, Kavouridis T, Leonis C, et al. Geochemical exploration of the three most significant geothermal areas of Lesbos Island, Greece. Geothermics, 1989, 18: 465-475

62 Bowers T S, Jackson K J, Helgeson H C. Equilibrium Activity Diagrams: For Coexisting Minerals and Aqueous Solutions at Pressures 
and Temperatures to $5 \mathrm{~kb}$ and $600^{\circ} \mathrm{C}$. Berlin: Springer, 1984. 1-397

63 Marini L, Fung A Y, Sanchez E. Use of reaction path modeling to identify the processes governing the generation of neutral $\mathrm{Na}-\mathrm{Cl}$ and acidic $\mathrm{Na}-\mathrm{Cl}-\mathrm{SO}_{4}$ deep geothermal liquids at Miravalles geothermal system, Costa Rica. J Volcanol Geoth Res, 2003, 128: 363-387

64 Parkhurst D L, Appelo C A J. User guide to PHREEQC (version 2) a computer program for speciation, batch-reaction, one-dimensional transport, and inverse geochemical calculations. US Geol Surv WaterResour Invest Rep, 1999. 99-4259

65 Can I. A new improved $\mathrm{Na} / \mathrm{K}$ geothermometer by artificial neural networks. Geothermics, 2002, 31: 751-760

66 He L Q, Lin J C, Shi B. Fick's Law and the Diffusion's Thermodynamics Theory (in Chinese). J Anqing Teach Coll (Nat Sci ed.), 2006, 12: 38-39

67 Berg H C. Random Walks in Biology, Princeton: PUP, 1993. 1-164

68 Feynman R P, Leighton R B, Sands M. The Feynman Lectures on Physics. The Definitive and Extended Edition, 2/E. New York: Addison-Wesley Publishing Co, 2006. 422-620

69 Crank J. The Mathematics of Diffusion. 2nd ed. New York: OUP, 1980. $1-424$

Open Access This article is distributed under the terms of the Creative Commons Attribution License which permits any use, distribution, and reproduction in any medium, provided the original author(s) and source are credited. 